\title{
A Glance at Community Safety-Evidence of the European Social Survey
}

\author{
Dr. Nasios Orinos \\ Director - Cyprus College \\ Address: 6 Diogenes Street, Engomi, 1516, Nicosia, Cyprus \\ Soulla Antoniadou \\ Mary Koumbari \\ Instructor - Cyprus College \\ Address: 6 Diogenes Street, Engomi, 1516, Nicosia, Cyprus
}

\begin{abstract}
This article discusses Cypriots' feeling of unsafety when walking alone in local areas. The article more specifically discusses how safe Cypriots feel walking alone in their local areas after dark, as opposed to Europeans, concentrating on the gender differences. In addition, the article touches burglary or physical assault percentages in Cyprus.
\end{abstract}

Keywords: Unsafety, local area, dark, European Social Survey, Cypriots, Europeans

\section{Introduction}

This paper portrays that European Social Survey is a unique, academically driven social survey that has a major impact from different angles. The paper starts by citing a theoretical background highlighting 'fear' and 'feeling of unsafety' especially among women. Furthermore, the paper provides the methodology used in the survey explaining in detail how the survey is organized, sampled, executed and analyzed. The last part of the paper provides the results of specific topics as derived from European Social Survey, concentrating on the feeling of safety when walking alone in local area after dark presenting the differences by gender, as well as the household member victim of burglary/physical assault during the last 5 years.

European Social Survey - A glance at community safety

\section{Theoretical Background}

Community promotes the positive feeling of belonging and safety. Nowadays, the sense of belonging and safety has been replaced by isolation, fear and anxiety, as a result of globalization and technology (Block, 2018). Occasionally, the feeling of fear is socially produced by high publicized media stories, police warnings as well as parental advices and school classes about crime prevention. We are able to produce mental maps of unsafe places and fearful environments based on experiences and the area reputation (Bennett et al, 2007). According to Gray et al (2011) 'fear' insufficiently capture most individual emotions regarding the threat of becoming victim of crime. Jackson and Gouseti, (2012) support that fear can be characterized as a powerful physical response to a direct and proximal threat and even some of the times, this could be an important descriptor of some individual's emotions in certain circumstances, individual's emotions regarding crime are usually closer to a sort of rumination or stress about risk and unsure threat. Individuals can react to a direct threatening context, but additionally can be extremely worried regarding a distant possibility of harm. According to Condon, Liever and Maillochon (2007) "feeling unsafe" is introduced in the political and public context as the phenomenon that influences individuals in the same way despite of social and gender differences. Nevertheless, Riger, Gordon and Lebailly (1978) affirm that females are the ones who usually tend to perceive themselves more vulnerable than men. Walklate (2018), observed that in 2007 the violence against women was a public anathema that raised tension for crime prevention and community safety. It is worth mention, the rate of rapes was doubled between 1990 and 2007 as well as the women killed in incident of domestic violence (Aebi et al, 2010). Some research outcomes indicate that when fear of crime rates are combined with officially registered victimizations, it is very often revealed that female and particularly elderly women are the ones that afraid more the possibility of crime but has less chance of being victimized than young men. On the contrary, young men that are most likely to be victimized are very much less fearful of crime (Gilchrist et al, 1998). Warr (1985) argues that research has shown that most of the women often feel vulnerable in their local communities and in public places because of their fear of rape. Women continually think they're in danger and someone could attack them especially when they walk through public areas after a certain hour (Stanko, 1990). Bennett et al (2007), identified that living in a neighbourhood which is perceived unsafe, reduce the confidence of walking during night time and this feeling was more intense among women than men. 
Therefore, women living in poor neighbourhoods are typically afraid of being assault in the street, especially older women. Also women from nonwhite ethnic backgrounds, experience high levels of fear in their neighbourhood in comparison with white women. Moreover, various women consider multistory parking, bus stops, public transportation and city centers dangerous and will avoid those areas for their personal safety (Bennett et al, 2007). In addition, the presence or absence of street lighting is associated with the feelings of safety (Stafford et al, 2018). Fotios et al (2015) experiment outcomes, using unfocussed, qualitative procedure, confirm that lighting was closely related with 'reassurance' when the process did not prompt focus on lighting. Based on the authors a road in which reassurance form lighting offers certainty and confidence to walk is the one that provides increased perceived safety and decreased fear of crime. The feeling of fear is higher in late time hours as there are less people around, something that contributes in feeling isolation from assistance if needed, while additionally because of the lower visibility, which may enhance offenders with more chances for concealment. Moreover low visibility may make it harder to distinguish escape routes (Fotios et al, 2015). Alfonzo (2005) distinguishes three separate types of walking namely 'destination walking', 'strolling walking' and 'combination walking' while additionally defines the different motivations that exist behind these that may affect the importance of lighting. The author explicates with an example that 'optional' strolling walking it might be easier affected than 'compulsory' destination walking. Gruszczynska (2004) supports that the enlargement of European Union meant greater population and social changes that increased criminal opportunities. Crime was developed on individual scale (theft, robbery and assaults), due to the weakness of the police to react appropriately and fast to the increased level of crime.

As well as on economic scale, due to the pursuit of financial success. The percentage of crime that was reported to the police according to Gruszczynska (2004) was significantly lower in Central and Eastern Europe countries (including Cyprus), than in Western Europe. Moreover, Aebi et al (2010) report that property offences such as domestic burglary, theft and vehicle theft, have been decreased and are related with the socioeconomic changes in Europe and the improvement of security measures in households. On the other hand, violent offences like robbery, assault and homicide, have been increased and can be justify by numerous factors, including the Internet development, the changes in youths lifestyle and free time, the growth of heavy alcohol consumption, the street gangs and the demographic changes. In addition to that, youths who are second generation of ethnic minorities have been increased and are related to the development of street gangs in Europe, which present high level of violent offenses and drug trafficking involvement (Aebi et al, 2010). According to Cyprus statistical service (2019), the number of serious offences reported in 2016 to the Police was 5.236 and in 2017 the number was 5.228. In both years, the offences against property had the largest percentage of 53,8\% and $49.8 \%$ respectively.

Both years 2016 and 2017, almost half of the victims were receivers of offences injurious to the public in general, while about two thirds of the victims were receivers of offences against property. Regarding the citizenship of offenders in the year of 2016, 54,1\% were Cypriots and 24,6\% were EU-28 citizens. In the year of 2017, 50,7\% were Cypriots and $28,7 \%$ were non EU citizens. Concerning juvenile criminality, 131 juveniles were involved in the commission of offences in 2016, of which 18 were girls. There were 99 juveniles involved in serious offences and 32 in minor offenses. During 2017, the total number of juveniles that were involved in the commission of offences were 107, of those only 5 were girls. There were 66 juveniles involved in serious offences and 41 in minor offences. Both years 2016 and 2017, the largest amount of juveniles were Cypriot citizens. Henson and Reyns (n, d) notes that various studies have been conducted with the objective of comprehending, monitoring and investigating fear of crime, with a large number of those outline and concluding that 'such fear continues to impinge upon the well-being of a proportion of the population". Nevertheless Farrall and Gadd (2004) support that few researchers have investigated the frequency that individuals feel the fear of crime and suggest in their research that few people fear crime frequently.

\section{Methodology}

\subsection{Research type}

European Social Survey (ESS) is a quantitative approached survey with the task to discover and calibrate crosscultural and cross-national differences in people's responses. Specification for European Social Survey (2018) explains well the survey's two elements. The ESS source questionnaire consists of a collection of questions that can be classified into two main parts, a core section and a rotating section. The ESS was primarily designed as a time series that could monitor changing attitudes and values across Europe. For this reason its questionnaire comprises a core module, containing items measuring a range of topics of enduring interest to the social sciences as well as the most comprehensive set of socio-structural variables of any cross-national survey. The exact number of items can change from round to round, but each question has a unique variable name to assist users working with data over time. Furthermore, in each ESS round, multi-national teams of researchers are selected to contribute to the design of two rotating modules for the questionnaire. Rotating modules are selected following an open call for proposals. Applicants may apply for 'new' modules or 'repeat' ones, which allow comparisons with previous ESS Rounds. 


\subsection{Sample size and structure}

According to European Social Survey, sampling principles and requirements (2018), the objective of the ESS sampling strategy is the design and implementation of workable and equivalent sampling strategies in all participating countries. This concept stands for random samples with estimates of comparable precision based on full coverage of the eligible residential populations aged 15+. The actual method of achieving this requirement varies considerably between participating countries, depending on their access to sampling sources and other considerations. But it is based on the same basic principles of strict probability and representativeness. Sampling principles and requirements (2018) state that all countries must aim for a minimum effective achieved sample size of 1500 or 800 in countries with ESS populations of less than two million after discounting for design effects. In Cyprus, a total of around 1600 sampling points are set up front. The sample is representative of all individuals aged 15 and over from 1600households, who are permanent residents, regardless of nationality, citizenship, language or legal status. The selection of people who respond to the questionnaire from every household is done with the method of the last birthday so that representativeness is ensured. Households are randomly selected and then oneperson from each household is drawn again also randomly and anonymously. This means that households and individuals that are drawn across the country cannot be exchangeable with others. Once an individual has been selected, under no circumstances can be substituted by another individual. Interviewers must attempt to make contact at every household or with every individual in their assignment except those notified as refusals. Interviewers must make a personal visit on a minimum of 4 occasions, at different times of the day and spread across the fieldwork period before they classify the household or individual as unproductive. At least one of these personal visits should be in the evening and one at the weekend. A high response rate is essential in order to ensure that the people interviewed in the survey accurately represent the population, so a target minimum response rate of $70 \%$ has been set. In Cyprus - Round 9 - atotal of 1600 sampling points were set up front, out of which Cyprus had succeeded a sample of 781 individuals aged 15+. Out of these, $53 \%$ were female and $47 \%$ were male. The results of this paper are based on this sample. Considering the Cyprus population, the maximum margin of error, at a 95\% confidence level associated with the aforementioned sample size, is plus / minus $3.5 \%$ at an overall level.

\subsection{Gathering data}

The wave under consideration, that is, wave 9, was conducted between October 2018 -April 2019. European Social Survey, sampling principles and requirements (2018), note that the mode of European Social Survey data collection in all countries is face-to-face interviewing via CAPI system. Through this method it is easier to boost response rates and achieve consistent data quality across diverse nations. Furthermore, European Social Survey aims at reducing possible bias caused by nonresponse and outline the steps taken to achieve this. First, as the sampling principles and requirements (2018) highlight, a minimum target national response rate of $70 \%$ is set up front recognizing that the target will not universally be achieved. Since response rates cannot be forecasted, the survey insists instead on certain fieldwork procedures in all countries that help maximize the chances of recruiting. For instance, to reduce refusals, the survey insists on personal briefings of all interviewers in doorstep interactions and the consideration of a range of response maximization techniques, such as advance letters. In addition, at least four visits have to be made before abandoning a sampling unit as non-productive, with calls spread across times of day and days of week. Similarly, to ensure that difficult to contact or busy people are consistently pursued, a minimum fieldwork duration of 30 days has been specified, but at the same time to reduce seasonal effects, a maximum time window of four months has been set. Most importantly, outcome codes are completed for each contact at each address on standardized contact forms. These include interviewer recorded observations of the household and its neighbourhood. This enables response patterns to be identified and subsequently response rates and nonresponsive to be consistently documented and calculated across countries.

\subsection{Analysis}

Data is analyzed in SPSS (Statistical Package of Social Sciences). Analyses employ both descriptive and inductive. Descriptive analysis involves the examination of frequencies and inductive employs the use of Hypothesis Testing for verification of the results. To provide some evidence of the degree of validity, the research design utilizesface validity.

Face validity refers to the subjective agreement of professionals that a scale logically appears to be accurately reflecting what it purports to measure and is just based on a close reading and study of the question.

\section{Hypothesis Testing - the empirical verification of results}

According to Orinos (2014), hypothesis testing enables the validation of the findings of the study by empirical means. The rationale behind this decision is grounded to the need of using inferential statistics in order to verify the results and make inferences about the population under investigation. 
For the purpose of this paper, a decision was made to adopt Hypothesis Testing. The rationale behind this decision was made after reviewing the relevant literature and considering views by leading scholars such as Zikmund (2003) and Norusis (1999)."In marketing theory a hypothesis is an unproven proposition or supposition that tentatively explains certain facts or phenomena - it is a statement of assumption about the nature of the world. In its simplest form, the hypothesis is a guess" (Zikmund, 2003).

With statistical techniques we are able to decide whether or not our theoretical hypothesis is confirmed by the empirical evidence. This is basically done by testing the null and alternative hypotheses

A null hypothesis is a statement that asserts that any change from what has been thought to be true will be due entirely to random sampling error (no significance). The true purpose of setting up the null hypothesis is to provide an opportunity for nullifying it. The alternative hypothesis states the opposite of the null hypothesis.

One of the things we wish to test in this project is whether interest in politics or satisfaction on institutions is indeed low. A hypothesis that interest or satisfaction is low is a null hypothesis, that is, it describes a hypothetical but exact state of affairs. The alternative hypothesis describes the situation when the null hypothesis is false. When we statistically test a hypothesis, we assume that the null hypothesis correctly describes the state of affairs. The null hypothesis is the frame of reference against which we will judge our sample results.

\section{What is Hypothesis (significance) testing}

Orinos (2014) further explains, that we generally assign the symbol $\mathrm{H}_{0}$ to the null hypothesis and the symbol $\mathrm{H}_{1}$ to the alternative hypothesis. The purpose of hypothesis testing is to determine which of the two hypotheses is correct.

The t- tests provides a method by which we can compare two data sets. Conducting a t- test informs us whether the degree of difference between the two data sets could be due to factors other than sampling error. If the results indicate that the difference between the groups is not likely due to sampling error, we believe that the two data sets probably do not come from the same population, or else are not equal with each other (are statistically significant). In significance testing we set a critical value which our observed t- statistic value should exceed if we are to say that the means are SIGNIFICANTLY DIFFERENT FROM EACH OTHER. When the t statistic values are extreme we think the two samples are from different populations (reject the null hypothesis and accept the alternative hypothesis). We say the two sample means are statistically significantly different from each other (there is a real significant difference between them, therefore we can generalize about our population).

Regarding the analysis in this paper, the variables that are used are the following: feeling of safety of walking alone after dark, household burglary/assault in the last 5 years and gender.

\subsection{Ethical Considerations}

Great emphasis is given to the ethical aspect of the study. As Zikmund (2003) points out, ethical issues in survey research are of primary importance. As he notes, the respondent's right to privacy, use of deception, the respondent's right to be informed about the purpose of the research, the need for confidentiality, the need for honesty and objectivity in collecting and reporting data, and other issues are factors in the design and execution of surveys. According to European Social Survey,project instructions (2010), to ensure that the survey is in line with European laws and directives on data protection, three main points are conveyed to respondents, whether in written or oral form. First, participation in the European Social Survey is voluntary and second the data are stored at and are available from the Norwegian Social Science Data Services. Theyare released for statistical purposes onlyfrom the Norwegian Social Science Data Services that takes all necessary steps to make it impossible for any user to directly identify any of the individuals who supplied the data. Third, an advance letter is always sent to each selected household. Respondents prefer having an advance letter which provides them with advance notice and enables interviewers to avoid a refusal.

\section{Analysis}

The analysis provides a descriptive analysis of the results followed by a Hypothesis Testing for verification of the results.

\subsection{Feeling of safety of walking alone}

Even though the majority of Cypriots feel safe walking alone in local area after dark, it is noted that 1 in 4 Cypriots feel unsafe. This percentage is a bit higher than European average. Country breakdown highlights that Norway, Slovenia, Finland, Switzerland and Poland are safer countries. These countries score unsafety rates way below the European average. Specifically, the five countries score unsafety rates of only 5\%, 6\%,7\%, 9\% and $10 \%$ respectively. Estonia, Netherlands and Belgium also score low unsafety rates. On the contrary, citizens in Bulgaria are way the most reluctant of walking alone in local areas after dark with unsafety rate of the amazing 
53\%. Italy, United Kingdom, Germany and France, also score high unsafety rates, specifically at 30\%, 25\%, $23 \%$ and $23 \%$ respectively.

\section{Figure I - Feeling of Safety Walking Alone In Local Area after Dark}

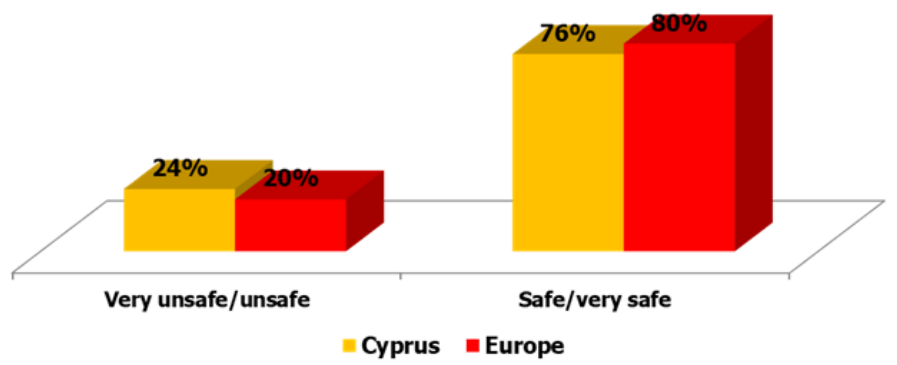

Interestingly, thegender breakdown showsthat women are a lot more refrained from walking alone in their local area after dark. 30\% of Cypriot women, as opposed to $17 \%$ of Cypriot men, are afraid of walking alone. European average is very close to the Cypriot one, with $27 \%$ of European women afraid of walking alone.

Figure Ii - Feeling of Safety Walking Alone In Local Area after Dark by Gender

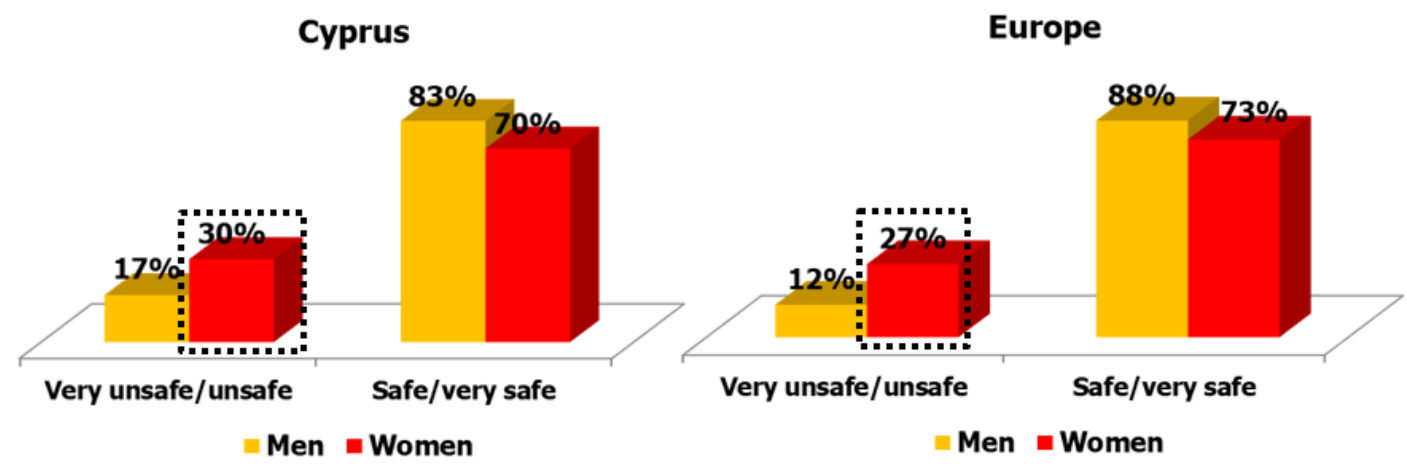

\subsection{Victim of a burglary or physical assault last 5 years}

Around $15 \%$ of Cypriots report to have personally, or a member of their household, been a victim of a burglary or physical assault during the last 5 years. European average is about the same.

Figure Iii - Household Member Victim of Burglary/Physical Assault during the Last 5 Years

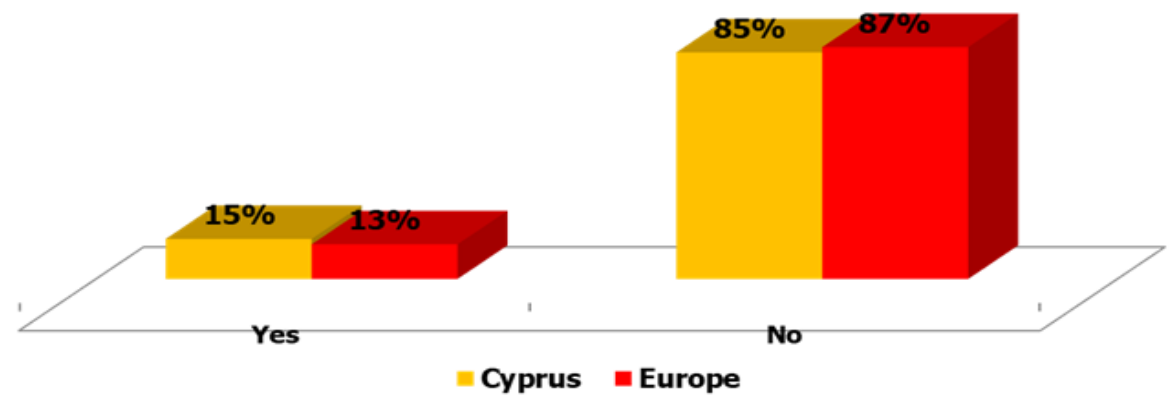

\subsection{Hypothesis Testing}

\section{The Chi-Square test for Goodness of Fit}

Significance level is defined as the level at which we are significant (5\%), the level which is considered too low to warrant support of the null hypothesis so we have to reject it.

Additionally, confidence level is defined as the percentage that indicates the long-run probability that the results will be correct. Traditionally, researchers have used the $95 \%$ confidence level.

Testing a hypothesis about a mean, requires interval data or ratio data. When we wish to work with a nominal scale such as with a Yes or No answer, because of the type of scale, we may use the Chi-square approach. 
The chi-square test allows us to test for significance in the analysis of frequency distributions. Thus categorical data on variables such as gender, education, or dichotomous (yes or no) answers may be statistically analyzed.

Test 1

At this point we wish to test the null hypothesis for the questions discussed earlier. Firstly, we wish to test whether the number of Cypriots who feel safe walking alone in local area after dark equals the number of Cypriots who feel unsafe.

Ho: $\mu 1=\mu 2$

$\mathrm{H} 1: \mu 1 \neq \mu 2$

Our frequency distribution (based on our sample) suggests that the majority of the population (76\%) feels safe walking alone in local area after dark.

The computed chi-square value needs to be compared with the critical chi-square value associated with the $\mathbf{0 5}$ probability level with 1 degree of freedom (remember, degrees of freedom refers to the number of observations that can be varied without changing the constraints or assumptions associated with a numerical system $=d f=k-1$ where $\mathrm{k}=$ the number of categorical responses-thus $d f=2-1=1$ ). From the chi-square table the chi-square critical value is 3.84. Since the calculated chi-square (214) is way higher than the tabular one, the null hypothesis - that the number of Cypriots who feel safe walking alone in local area after dark equals the number of Cypriots who feel unsafe- IS REJECTED.

Therefore we conclude that on a 95\% confidence level there is enough evidence to support that the number of Cypriots who feel safe walking alone in local area after dark is higher than the number of Cypriots who feel unsafe.

Therefore on this we can generalize on the population.

TABLE I - Chi-Square Test for Feeling of safety - Cyprus
$\begin{aligned} & \text { Feeling of safety of walking alone in local area } \\
& \text { after dark } \\
& \text { Observed N }\end{aligned}$
\begin{tabular}{l|r|r|r} 
Expected N & Residual \\
\hline Very safe/safe & 595 & 390.5 & 204.5 \\
\hline Unsafe/very unsafe & 186 & 390.5 & -204.5 \\
\hline Total & 781 & & \\
\hline
\end{tabular}

Test Statistics

\begin{tabular}{|c|c|}
\hline & $\begin{array}{c}\text { Feeling of } \\
\text { safety of } \\
\text { walking alone } \\
\text { in local area } \\
\text { after dark }\end{array}$ \\
\hline Chi-Square & $214.188^{a}$ \\
\hline df & 1 \\
\hline Asymp. Sig. & .000 \\
\hline \multicolumn{2}{|c|}{$\begin{array}{l}\text { a. } 0 \text { cells }(0.0 \%) \text { have } \\
\text { expected frequencies } \\
\text { less than } 5 \text {. The } \\
\text { minimum expected } \\
\text { cell frequency is } \\
390.5 \text {. }\end{array}$} \\
\hline
\end{tabular}

\section{$\underline{\text { Test } 2}$}

In the same way we tested the null hypothesis that Europeans (European average) who feel safe walking alone in local area after dark equals the number of Europeans who feel unsafe.

Ho: $\mu 1=\mu 2$

$\mathrm{H} 1: \mu 1 \neq \mu 2$ 
Using the same procedure we see that the calculated chi-square (12767) is higher than the tabular one, $\mathbf{3 . 8 4}$,so the null hypothesis - that the number of Europeans (European average) who feel safe walking alone in local area after dark equals the number of Europeans who feel unsafe - IS REJECTED.

Therefore we conclude that on a 95\% confidence level there is enough evidence to support that the number of Europeans who feel safe walking alone in local area after dark is higher than the number of Europeans who feel unsafe.

Therefore on this we can also generalize on the population.

\section{TABLE II - Chi-Square Test for Feeling of safety - Europe \\ Feeling of safety of walking alone in local area after dark}

\begin{tabular}{l|r|r|r} 
& Observed N & Expected N & Residual \\
\hline Very safe/safe & 28517 & 17844.0 & 10673.0 \\
\hline Unsafe/very unsafe & 7171 & 17844.0 & -10673.0 \\
\hline Total & 35688 & & \\
\hline
\end{tabular}

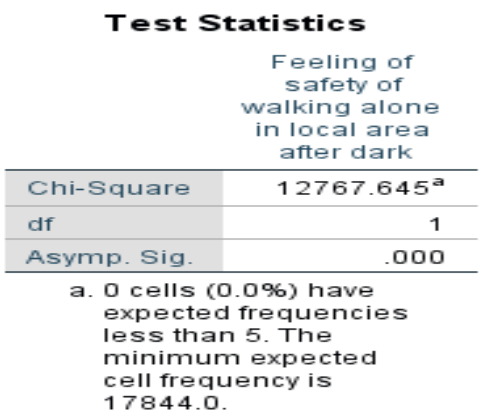

$\underline{\text { Test } 3}$

In the same way we tested the null hypothesis that Cypriots who have personally, or a household member, been a victim of burglary/assault in the last 5 years equals the number of Cypriots who have not been a victim.

Ho: $\mu 1=\mu 2$

$\mathrm{H} 1: \mu 1 \neq \mu 2$

Using the same procedure we see that the calculated chi-square (388) is higher than the tabular one,3.84, so the null hypothesis - Cypriots who have personally, or a household member, been a victim of burglary/assault in the last 5 years equals the number of Cypriots who have not been a victim - IS REJECTED.

Therefore we conclude that on a 95\% confidence level there is enough evidence to support that the number of Cypriots who have not been a victim of burglary/assault in the last 5 years is higher than the number of Cypriots who have.

Therefore on this we can also generalize on the population.

TABLE III - Chi-Square Test for victim of burglary -Cyprus

Respondent or household member victim of burglarylassault last 5 years

\begin{tabular}{l|r|r|r} 
& Observed N & Expected N & Residual \\
\hline Yes & 115 & 390.5 & -275.5 \\
\hline No & 666 & 390.5 & 275.5 \\
\hline Total & 781 & & \\
\hline
\end{tabular}




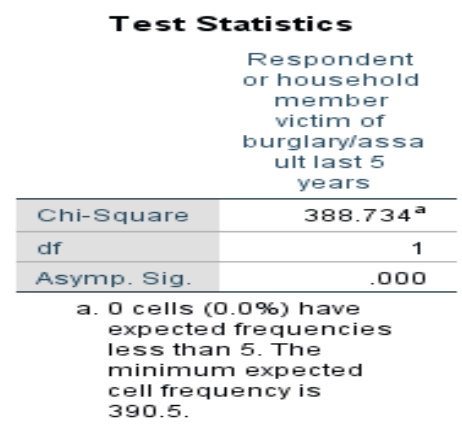

\section{Test 4}

In the same way we tested the null hypothesis that Europeans who have personally, or a household member, been a victim of burglary/assault in the last 5 years equals the number of Europeans who have not been a victim.

Ho: $\mu 1=\mu 2$

$\mathrm{H} 1: \mu 1 \neq \mu 2$

Using the same procedure we see that the calculated chi-square (19456) is higher than the tabular one,3.84,so the null hypothesis - Europeans who have personally, or a household member, been a victim of burglary/assault in the last 5 years equals the number of Europeans who have not been a victim - IS REJECTED.

Therefore we conclude that on a $95 \%$ confidence level there is enough evidence to support that he number of Europeans who have not been a victim of burglary/assault in the last 5 years is higher than the number of Europeans who have.

Therefore on this we can also generalize on the population.

TABLE IV - Chi-Square Test for victim of burglary - Europe

Respondent or household member victim of burglarylassault last 5 years

\begin{tabular}{lr|r|r} 
& Observed N & Expected N & Residual \\
\hline Yes & 4724 & 17931.5 & -13207.5 \\
\hline No & 31139 & 17931.5 & 13207.5 \\
\hline Total & 35863 & & \\
\hline
\end{tabular}

\begin{tabular}{|c|c|}
\hline \multicolumn{2}{|c|}{ Test Statistics } \\
\hline & $\begin{array}{l}\text { Respondent } \\
\text { or household } \\
\text { member } \\
\text { victim of } \\
\text { burglarylassa } \\
\text { ult last } 5 \\
\text { years }\end{array}$ \\
\hline Chi-Square & $19456.047^{a}$ \\
\hline df & 1 \\
\hline Asymp. Sig. & .000 \\
\hline \multicolumn{2}{|c|}{$\begin{array}{l}\text { a. } 0 \text { cells }(0.0 \%) \text { have } \\
\text { expected frequencies } \\
\text { less than } 5 \text {. The } \\
\text { minimum expected } \\
\text { cell frequency is } \\
17931.5 \text {. }\end{array}$} \\
\hline
\end{tabular}

\section{$\underline{\text { Test } 5}$}

In the following test we wish to test the null hypothesis that feeling of safety in walking alone in the dark is equal by gender.

Ho: $\mu 1=\mu 2$

$\mathrm{H} 1: \mu 1 \neq \mu 2$

Using the same procedure we see that the calculated chi-square (19) is way higher than the tabular one,3.84,so the null hypothesis - that feeling of safety in walking alone in the dark is equal by gender - IS REJECTED.

Therefore we conclude that on a 95\% confidence level there is enough evidence to support that women are a lot more refrained from walking alone in their local area after dark than men, both for Cypriots and Europeans. 
Therefore on this we can generalize on the population.

\begin{tabular}{|c|c|c|c|c|c|}
\hline \multicolumn{6}{|c|}{$\begin{array}{c}\text { Feeling of safety of walking alone in local area after dark * Gender } \\
\text { Crosstabulation }\end{array}$} \\
\hline & & & \multicolumn{2}{|c|}{ Gender } & \multirow[b]{2}{*}{ Total } \\
\hline & & & Male & Female & \\
\hline \multirow{6}{*}{$\begin{array}{l}\text { Feeling of safety of } \\
\text { walking alone in local } \\
\text { area after dark }\end{array}$} & \multirow[t]{3}{*}{ Very safe/safe } & Count & 305 & 290 & 595 \\
\hline & & 96 within Gender & 83.396 & $69.9 \%$ & $76.2 \%$ \\
\hline & & 96 of Total & $39.1 \%$ & $37.1 \%$ & $76.2 \%$ \\
\hline & \multirow[t]{3}{*}{ Unsafe/very unsafe } & Count & 61 & 125 & 186 \\
\hline & & 96 within Gender & $16.7 \%$ & $30.1 \%$ & $23.8 \%$ \\
\hline & & $\%$ of Total & $7.8 \%$ & $16.0 \%$ & $23.8 \%$ \\
\hline \multirow[t]{3}{*}{ Total } & & Count & 366 & 415 & 781 \\
\hline & & 96 within Gender & $100.0 \%$ & $100.0 \%$ & $100.0 \%$ \\
\hline & & 96 of Total & $46.9 \%$ & 53.196 & $100.0 \%$ \\
\hline
\end{tabular}

\begin{tabular}{|c|c|c|c|}
\hline \multicolumn{4}{|c|}{ Chi-Square Tests } \\
\hline & Value & df & $\begin{array}{l}\text { Asymptotic } \\
\text { Significance } \\
\text { (2-sided) }\end{array}$ \\
\hline Pearson Chi-Square & $19.402^{a}$ & 1 & .000 \\
\hline Continuity Correction ${ }^{b}$ & 18.667 & 1 & .000 \\
\hline Likelihood Ratio & 19.780 & 1 & .000 \\
\hline $\begin{array}{l}\text { Linear-by-Linear } \\
\text { Association }\end{array}$ & 19.377 & 1 & .000 \\
\hline$N$ of Valid Cases & 781 & & \\
\hline
\end{tabular}

TABLE VI - Chi-Square Test for feeling of safety by gender - Europe Feeling of safety of walking alone in local area after dark * Gender Crosstabulation

\begin{tabular}{|c|c|c|c|c|c|}
\hline & & & \multicolumn{2}{|c|}{ Gender } & \multirow[b]{2}{*}{ Total } \\
\hline & & & Male & Female & \\
\hline \multirow{6}{*}{$\begin{array}{l}\text { Feeling of safety of } \\
\text { walking alone in local } \\
\text { area after dark }\end{array}$} & \multirow[t]{3}{*}{ Very safe/safe } & Count & 14867 & 13650 & 28517 \\
\hline & & \%o within Gender & $88.1 \%$ & $72.5 \%$ & $79.9 \%$ \\
\hline & & $\%$ of Total & $41.7 \%$ & $38.2 \%$ & $79.9 \%$ \\
\hline & \multirow[t]{3}{*}{ Unsafe/very unsafe } & Count & 2006 & 5165 & 7171 \\
\hline & & $\%$ within Gender & $11.9 \%$ & $27.5 \%$ & $20.1 \%$ \\
\hline & & $\%$ of Total & $5.6 \%$ & $14.5 \%$ & $20.1 \%$ \\
\hline \multirow[t]{3}{*}{ Total } & & Count & 16873 & 18815 & 35688 \\
\hline & & $\%$ within Gender & $100.0 \%$ & $100.0 \%$ & $100.0 \%$ \\
\hline & & $\%$ of Total & $47.3 \%$ & $52.7 \%$ & $100.0 \%$ \\
\hline
\end{tabular}

Chi-Square Tests

\begin{tabular}{|c|c|c|c|}
\hline & Value & df & $\begin{array}{l}\text { Asymptotic } \\
\text { Significance } \\
\text { (2-sided) }\end{array}$ \\
\hline Pearson Chi-Square & $1341.851^{a}$ & 1 & .000 \\
\hline Continuity Correction $^{b}$ & 1340.882 & 1 & .000 \\
\hline Likelihood Ratio & 1386.759 & 1 & .000 \\
\hline $\begin{array}{l}\text { Linear-by-Linear } \\
\text { Association }\end{array}$ & 1341.813 & 1 & .000 \\
\hline $\mathrm{N}$ of Valid Cases & 35688 & & \\
\hline
\end{tabular}

\section{Discussion}

The findings of the analysis point out that there is a relationship of the results with the literature. As a matter of fact the literature throws light to the reasons of why people, especially women, feel unsafe walking alone in the dark. A significant percentage of Cypriots, 24\%, feel unsafe walking alone in local area after dark with this percentage being a bit higher than the European average. Interestingly, the gender breakdown shows that women are a lot more refrained from walking alone in their local area after dark. 30\% of Cypriot women, as opposed to $17 \%$ of Cypriot men, are afraid of walking alone. 
Indeed, as the literature suggests, nowadays, the sense of belonging and safety has been replaced by isolation, fear and anxiety. Women are the ones who usually tend to perceive themselves more vulnerable that men. The literature notes that the rate of rapes was doubled between 1990 and 2007 as well as the women who were killed in incident of domestic violence. The literature further explains that most of the women often feel vulnerable in their local communities and in public places because of their fear of rape and they continually think they're in danger and someone could attack them especially when they walk through public areas after a certain hour. The fact that they might live in a neighbourhood which is perceived unsafe, reduces their confidence of walking during night time. The feeling is even higher in late time hours when there are less people around or low visibility.

\section{Conclusion}

In the above content, it appears that the question that lies before us is how do societies solve this problem and with what measures? Obviously, there is a gender-fear problem that needs attention not just in Cyprus. Neighbourhood oriented policing for example, is a measure taken in Houston - USA back in the 19980s. According to Brown (2002), the idea was based on a number of principles that were used at the time to shape this approach. It greatly involved the local community on the notion that when people have concerns about their neighbourhoods they will be involved, while at the same time it emphasized prevention services. As Brown (2002) notes, demands for service varied from one neighbourhood to another, and the police department's job was to recognize those differences and provide customized responses to solve problems. The department might have implemented a zero tolerance strategy in one neighbourhood, increasing police visibility in another or collaborating with community groups to address disorder issues in another.

\section{References}

Aebi, M. F. and Linde, A. (2010) 'Is There a Crime Drop in Western Europe?',pp 252-277.doi: 10.1007/s10610010-9130-y.

Alfonzo, M. (2005) 'To Walk or Not to Walk?: The Hierarchy of Walking Needs', Environment and Behavior, 37(6), pp. 808-836. Available at:

https://search-ebscohost-

com.liverpool.idm.oclc.org/login.aspx?direct=true \&db=eric\&AN=EJ734889\&site=eds-live \&scope=site

Bennett, G.G. and McNeill, L.H. and Wolin, K.Y. and Duncan, D.T. and Puleo, E. and Emmons, K.M. (2007) Safe to Walk? Neighborhood Safety and Physical Activity Among Public Housing Residents. doi: 10.1371/journal.pmed.0040306.

Block, P. (2018) Community: The Structure of Belonging. Second Edition. Berrett-Koehler Publishers Inc. pp 1-4

Brown, L. (2002) Neighborhood Oriented Policing, European Forum for urban safety, France

Condon, S, Lieber, M and Maillochon, F (2007) 'Feeling Unsafe in Public Places: Understanding Women's Fears', Revue française de sociologie, 48, p. 101. DOI 10.3917/rfs.485.0101

Cyprus Statistical Service. (2019) A1. Serious Offences Reported to the Police by Offence Group, 2005-2017. Available at:

https://www.mof.gov.cy/mof/cystat/statistics.nsf/populationcondition_27main_en/populationcondition_27 main_en?OpenForm\&sub=7\&sel=2

Cyprus Statistical Service. (2019) Latest Figures: Criminal Statistics 2016-2017. Available at: https://www.mof.gov.cy/mof/cystat/statistics.nsf/All/DD61987BD6586CF3C225841200341CDD/\$file/Cri me_Statistics-2016_2017-EN-120619.pdf?OpenElement

European Social Survey, (2018), Sampling for the European Social: Principles and Requirements.[Online]Available:

https://www.europeansocialsurvey.org/methodology/ess_methodology/sampling.html (December 20, 2019)

European Social Survey. (2018). Specification for ESS ERIC Member and Observer Countries April 2018.[Online]Available:https://www.europeansocialsurvey.org/methodology/ess_methodology/source_que stionnaire/(December 20, 2019)

Farrall, S and Gadd, D (2004) 'RESEARCH NOTE: The Frequency of the Fear of Crime', The British Journal of Criminology, 44(1), p. 127. Available at:

https://search-ebscohost

com.liverpool.idm.oclc.org/login.aspx?direct=true \&db=edsjsr\&AN=edsjsr.23639025\&site=eds-

live \&scope $=$ site

Fotios, S, Unwin, J and Farrall, S (2015), 'Road lighting and pedestrian assurance after dark: Are view', Lighting Res. Technol., Vol. 47: 449-469. Available at: https://journals.sagepub.com/doi/pdf/10.1177/1477153514524587

Gilchrist, E, Bannister, J, Ditton, J and Farrall, S (1998), 'WOMEN AND THE 'FEAR OF CRIME', British Journal of criminology, VOL.38 NO. 2. Available at:

https://www.sccjr.ac.uk/wp-content/uploads/2009/11/Women_and_the_fear_of_crime.pdf 
Gray, E, Jackson, J and Farrall, S (2011) 'FEELINGS AND FUNCTIONS IN THE FEAR OF CRIME: Applying a New Approach to Victimisation Insecurity', The British Journal of Criminology, 51(1), p. 75. doi: $10.1093 / \mathrm{bjc} / \mathrm{azq} 066$.

GruszczyŃska, B. (2004) 'Crime in Central and Eastern European Countries in the Enlarged Europe', European Journal on Criminal Policy and Research, 10(2-3), p. 123. doi: 10.1007/s10610-004-3784-2.

Henson, B. and Reyns, B. W. (no date) 'The only thing we have to fear is fear itself... and crime: The current state of the fear of crime literature and where it should go next', Sociology Compass, 9(2), pp. 91-103. doi: $10.1111 / \operatorname{soc} 4.12240$.

Jackson, J. and Gouseti, I., (2012), 'Fear of Crime and the Psychology of Risk', entry in Bruinsma, G. and Wesiburd, D. (eds.) Encyclopedia of Criminology and Criminal Justice, Springer-Verlag, Forthcoming. Available at SSRN: https://ssrn.com/abstract=2141537 or http://dx.doi.org/10.2139/ssrn.2141537

Orinos, N (2014), 'A Glance at Satisfaction on Democracy-Evidence of the European Social Survey', Journal of Business \& Social Science, VOL.5 NO. 10 (1), pp 26-37. Available at: http://ijbssnet.com/view.php?u=http://ijbssnet.com/journals/Vol_5_No_10_1_September_2014/3.pdf

Norusis, M. (1999). Guide to Data Analysis. New Jersey: Prentice Hall.

RIGER, S., GORDON, M. and BAILLEY, R. (1978), "Women's Fear of Crime: From Blaming to Restricting the Victim', Victimology, 3: 274-84.Available at: http://bjc.oxfordjournals.org/

Stafford, A. and Hobson, J. and Heydon, S. andBruson, W. and Veryard, K. and Carruthers, R. and Mills, C. (2018) Community Safety and the Night Time Economy. University of Gloucestershire. Cheltenham UK. Available at: http://eprints.glos.ac.uk/5558/

Stanko, E. (1990), Everyday Violence: How Men and Women Experience Sexual and Physical Danger. London: Pandora.

Walklate, S. (2018) 'Reflections on community safety: the ongoing precarity of women's lives', Crime Prevention and Community Safety, 20(4), p. 284. doi: 10.1057/s41300-018-0050-y.

Warr. M (1985) 'Fear of Rape among Urban Women', Social Problems, 32(3), p. 238. doi: 10.2307/800684.

Zikmund, W. G. (2003). Exploring Research Methods. ( $8^{\text {th }}$ ed.). Ohio: Thomson, South Western. 